\author{
JACEK GĄDECKI* \\ University of Science and Technology AGH \\ MARCIN JEWDOKIMOW** \\ Cardinal Stefan Wyszyński University \\ MAGDALENA ŻADKOWSKA*** \\ Gdańsk University \\ https://doi.org/10.26485/PS/2018/67.4/4
}

\title{
ONE STUDY - DIFFERENT STORIES. THE MULTI-METHOD PERSPECTIVE IN STUDYING TELEWORK
}

\footnotetext{
Abstract

The main goal of the paper is a methodological reflection on telework studies that are realized in the private environment. We reconstruct the process of creating "the story" about telework that started from the "individualistic point" (his/her story) of the teleworker, treated as an individual, and ended up in a "collective point", that understands telework as a phenomenon that needs to be studied in reference to other local actors (their story) and is influenced by the autoethnographic perspective of the group of researchers (our story).

Keywords: telework, working unit, ethnography, multi-method perspective, dyadic interviews

* Dr hab., Katedra Socjologii Ogólnej i Antropologii Społecznej WH AGH w Krakowie; e-mail: jgadecki@agh.edu.pl

** Dr, Katedra Kultury XX i XXI wieku, IFKiK WNH UKSW;

e-mail: jewdokimow.marcin@gmail.com

*** Dr, Zakład Socjologii Życia Codziennego WNS UG w Gdańsku; e-mail: magdalena.zadkowska@ug.edu.pl
} 


\section{INTRODUCTION}

The aim of this article is to present the methodological challenges we faced in the course of a three-year-long ethnographic study of the influence of telework on Polish families ${ }^{1}$. Our research reflects important challenges characteristic of telework studies. Additionally, our reflection is related to various aspects of teleworking practices related to the following questions: who teleworks (is it just an individual or can we think about the "teleworking unit"?), where (how is the private space changing into the office space?) and when (how are the rhythms of private and work life orchestrated)? In our longitudinal and qualitative project, we sought to apply a multimethod perspective to study the impact of telework on private spaces and relationships among couples. In this text, we summarize the methodological challenges and raise several questions connected with the processual character of the study. To sum up, our ambition is to write more about what we did to explain and explore telework rather than to depict what we know about it after three years of qualitative research.

First of all, we will deal with the deconstruction of interviews. In the case of our research, the interviews were not just tools for collecting data, but they were also the subject of reflection. These comments relate to using different methods as well as the interview situation itself, as the key to getting a full picture of this particular form of work. In the text, we pay attention to how the identities of the teleworker, the teleworker's partner and the researcher (his/her gender and experiences) influenced the creation of the situation and access to information or its relational character. We are going to present the difference between the typical IDI interview and the dyadic interviews we used during the research ${ }^{2}$. Our task will be to show what common histories presented by the partners (called "their stories") give us: how they reveal communication problems and those related to routines of everyday life in a home where at least one person teleworks.

Secondly, we focus on the role of the self-reflection of researchers and the autoethnographic approach in the study of teleworking. We focus on the positions of the researchers themselves. A longitudinal research project shows how important it is to reveal his/her position and beliefs and to confront them with the beliefs of the respondents. In this sense, the personal placement as an academic

The paper was created as part of the project „So you are sitting at home ...” financed by the National Science Center granted on the basis of Decision No. DEC-2013/09/D/HS6/00437.

2 By the typical IDI we understand, for example, a series of two, separately conducted individual interviews, one with the teleworker and one with his/her partner. 
worker, a man/woman working at home, affects both the definition of the research problems and research questions and the analysis of the data received.

Finally, we present methods helpful to reach the reality of teleworkers' practices which were not mediated by the interview. It is a story without a language, based on time data and photos, but not by conversation nor by popular teleworking representations.

\section{THE METHODOLOGICAL AND THEORETICAL BACKGROUND OF THE STUDY PRESENTED IN THE PAPER}

Our research project, entitled "So you are staying at home?" focused on the boundaries between home and work, and the impact of telecommuting on the telecommuter and his or her family, including the question of roles related to paid and unpaid domestic work. Teleworking, even via ICT, requires the constant negotiation of borders, not only between the public and private spheres but also within the private space [see: Kaufmann 1995]. Following Silvia López Estrada, we distinguished between two ideal types of strategies used in telecommuting: (1) the segregation strategy (strongly separating the spheres of home into the paid workspace and domestic life space), and (2) the integration strategy (characterized by weak borders between work and domestic space) [Estrada 2002]. Control over the working process, flexible planning, help received from family members and their involvement in household work can reinforce integration strategies. The lack of boundaries at home between the two worlds, or their transgression, long working days, the presence of children in the workspace and a lack of co-responsibility of adult partners can cause tensions connected with teleworking. Forming these boundaries depends on three indicators: (1) how far other people move from one sphere into the other, (2) whether (and how) the household objects (from tools to decoration) and atmosphere are similar or different between the home and domestic life spaces, (3) whether and how our thoughts, activities, and ways of self-presentation in both spheres are similar/different [Nippert-Eng 1996: 8].

The aim of the study that we present in this paper was to capture and describe the tension caused by telework in the daily life of individuals. The study involved 36 households including at least one teleworker working from home in three Polish metropolitan areas (Warsaw, Kraków, and Tricity: Gdańsk, Gdynia, and Sopot) where the three authors of the study work. Individual semi-structured interviews were conducted both with the teleworkers and their partners (72 informants in total). In the final stage of the project, these interviews were supplemented with joint interviews conducted with the couples. The project relied on a qualitative 
approach since such a methodology makes it possible to examine how the publicprivate dichotomy is realized in particular household realities on a daily basis [Gabb, Fink 2018].

Thanks to semi-structured IDIs, one can catch the dynamics and multiplicity of representations and techniques which define the public and the private and create the borders between workplace and home. To capture the mindful "situation, feelings and context" [Gabb, Fink 2018] of the "relational space" among the actors [Swidler 2004], we decided to complement the interviews conducted with the teleworkers with interviews with their partners, and, in the final phase of the project, with dyadic interviews, as well as photo-autoethnography and daily diaries. This build-up of data allowed us to more fully understand the impact of teleworking on life, but it also increased the complexity of our analysis and required more time. For example, the teleworkers were equipped with disposable cameras (27 exposures), which allowed them to take at least three photos a day during the week of the self-observation.

The main theoretical frame originally applied in the study was Swidler's concept of "culture as a toolkit" [Swidler 2001]. We use the toolbox as a concept, but also as a powerful metaphor that describes the constructions and reconstructions of teleworkers' practices. If one opens a teleworker's toolbox, one can observe old, partially useful tools that can no longer be used to build teleworking environments, but also some new ones that have been adapted to the new circumstances. Some tools are missing from the toolbox - they have to be reinvented. Thus, by paraphrasing and adapting Swidler's concept one can say that the current toolbox is inadequate (some of the tools do not work) or incomplete.

It is not so much a set of tools that a creative individual can use, but a set of inconsistent and obstructive tools that an individual must transform and modify, such as the Internet (how can one cope with the drawbacks and avoid wasting time on Facebook?), home space (a comfortable home interior tempts with the promise of relaxation when it becomes a working space), or relationship with the partner (who wants to relax with us at home and has a set of clear or takenfor-granted expectations about work/non-work relations). In the toolbox, one can find time management practices, disciplinary practices, workplace programmes such as computers and smartphones, the space available for living, household habits, or prohibitions on social roles, etc. All these tools can be ascribed to three general categories: time, space and social roles:

1. space - the transformation of the private sphere of the home (as a place of realizing passions and expressing oneself) into a quasi-public space; 
2. time - the appropriation of the private space by the workspace leads to the collision of two different time systems: cyclical time (household work) and linear time (professional duties), which results in multiple rhythms that (more or less harmoniously) overlap; teleworkers and their relatives can experience conflicts between their professional, family, daily and festive calendars;

3. social roles - perhaps the most important part of this construction process is the production of a narrative about oneself as a teleworker. In the situation of telework, available social roles, which are elements of teleworking, are important on at least three levels: (1) individual: reflecting on oneself as a teleworker, (2) when dealing with partners and children (distinguishing between oneself as an employee and as a partner, especially in the context of paid and unpaid work at home), (3) in relation to other people: family members or neighbours. In this multidimensional process of constructing oneself as a teleworker, teleworking becomes a practice of emancipation or empowerment, an overt or covert necessity. The smooth «usage» of roles is processual rather than substantive. It is not a set of attitudes and values, but a constant narrative, an emanation of the role and position of a teleworker. Therefore, apart from individual interviews with teleworkers, we also decided to interview their partners and, finally, to conduct interviews in pairs; these conversations show how the individuals disagree, or offer different interpretations, etc.

\section{HOW CAN ONE WRITE THE "STORY" OF TELEWORK?}

\section{From Collective Researcher To Collective Author}

The main challenge we faced during our research was to capture the multidimensionality of telework as a social practice (focusing on time, space and social roles) and to achieve multivocality (by giving voice to the different actors involved in teleworking practices). To present the methodological reflections in the paper, we apply here the "six stories" concept introduced by Roshan Hertz in her study of the financial life of couples [Hertz 1995]. This concept and research diagram allow us to capture the tension we faced during the project: between the increase in the volume of data available for analysis on the one hand, and the rising complexity of the analysis on the other.

As Hertz wrote, when one talks about the life of a couple, one needs to be aware of at least four different stories: (1) "the story" - a story that can be grasped by a truly objective camera, (2) "her/his story" (in our case, the teleworker's one), (3) "his/her story" (in our case, the partner's version), (4) "their story" - the story 
negotiated by the couple as a whole. There are also two other stories that need to be taken into account to develop one's own reflexivity.

PICTURE 1. Six stories

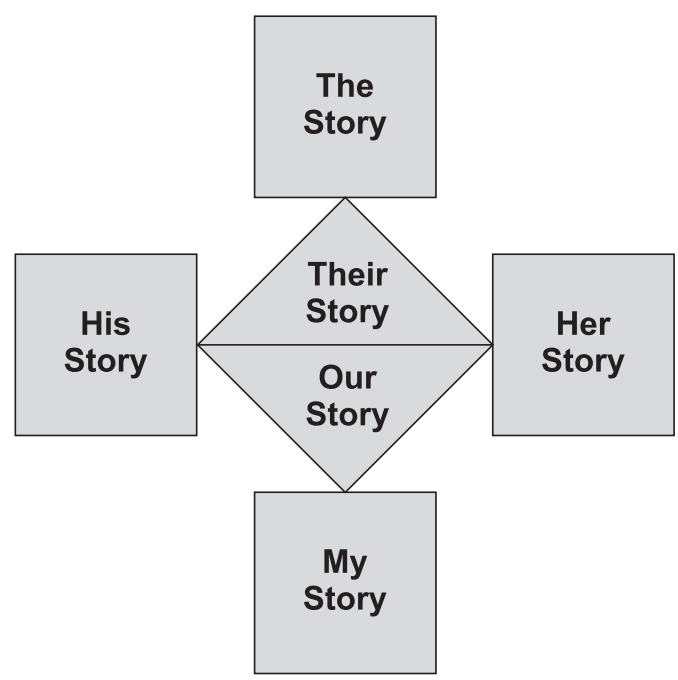

Source: [Hertz 1995: 448].

\section{FROM "HER/HIS STORY" TO "THEIR STORY"}

\section{From the Teleworker as an Individual to the Teleworking Unit}

While preparing the study, we discovered that the partners of teleworkers are often omitted in the studies of telework, and because of that, the entire sphere of the real impact of teleworking on the time of a couple, the space of the home or the dilemmas associated with the roles, disappear. To obtain access to the relational space between the actors we used dyadic interviews, also known as joint interviews, couple interviews, and conjoint interviews [see: Polak, Green 2016]; they seemed to fit our research problem and main questions perfectly. Considering that the partner may be completely unaware of some issues raised in individual interviews, joint interviews provide an opportunity to learn about them. By applying this method, we had an opportunity to access various aspects of the couple's knowledge (each partner talks about the same thing); it also helped to fill gaps in the memory of one partner [Seymour, Dix, Eardley, cited in Arksey 1996]. 
Jacqui Gabb and Janet Fink, in describing their methodology applied in the "Enduring Love" project, emphasize that the practical approach is crucial for the study of couples' lives. They use a multiple methods research design in a manner that can generate richly textured data on different dimensions of phenomena. Gabb calls this pieces of a jigsaw or fragments of data [Gabb 2009] that produce meaning through "each twist of the analytical kaleidoscope" [McCarthy, Holland, Gillies, 2003:19]. Following Gabb's methodological innovations [2009] we decided to introduce more tools to observe the individual his/her stories, as well as those of their partners and their stories as a couple.

Dyadic interviews provide an opportunity to capture the "teleworking unit", i.e., a quite common situation when the teleworker's partner becomes his/her co-worker. Considering the perspective of a couple (or "their story" in Hertz's categories) opens up the concept of telework to the supra-individual level - the couple becomes a real working subject. The relationship, cooperation, and arrangements with the partner influence the mode of teleworking, as they define the working time and the workplace. A partner of one of the teleworkers put it as follows:

There is always a risk that personal life may be invaded by work [...]. This is a very important aspect [of telework]. If I'm at home, I'm also involved in this work, although I don't get paid for it. There's always something to be done; there are questions, problems with the computer, with software. There's always something that comes up (KK6).

The tasks that belong to paid work duties are also executed after the official time for work is over, between other, domestic tasks. The respondents do feel the pressure and domination of paid work duties over domestic duties.

By using the concept of a "teleworking unit", we emphasize that the couple actually becomes a working subject, because the relationship, cooperation, and arrangements with the other person are crucial in establishing the conditions of the telework: work time, workplace, etc. It is the decision of the couple, not the individual. Of course, negotiations and arrangements are not always deliberate. Not everything in the teleworking unit is fixed and discussed; sometimes it just "works", which means that non-scientific social knowledge operates on a daily basis because of the worked-out and reworked routines that are helpful for the household members.

Thanks to the dyadic interviews, we got access to two important and complicated spheres of telework, i.e., the routines and the communication practices. The scenario prepared for the dyadic interview reflected the important moment when the teleworker's partner returned home from work. This difficult moment of 
returning home is crucial to understand the clash of the two rhythms, as well as the power of expectations related to the preparation of a meal, cleanliness at home, and the end of work. The reconstruction of routines and their changes showed that routines that initially favor the separation of roles over time - with changing situations - can become important constraints: the routines caused a lot of problems that could be captured and analyzed only thanks to the dyadic interview. What is more, the scenarios stressed the role of communication between the couples. As sociologists know, by establishing a role, an individual communicates it to others and thus indicates how to proceed in a given situation. Informed in this way, the participants will know how to act in order to trigger the desired response [Goffman 1981]. The roles, therefore, remain the result of negotiations between the person performing the role and the people with whom he/she interacts. These negotiations are also a communication task. Communication is necessary, not only to define the roles but also to maintain boundaries between the many roles performed by a specific person, e.g., the role of an employee with the role of a partner or a parent. The role boundary is a set of expected or acceptable actions, negotiated between people with relatively clear roles. In the case of teleworkers, communication about their role seems to be an important and time-consuming part of their working day. It is crucial for others - from partners and children to clients and friends - that they provide information about whether they are still at work or have already finished. In this case, "their stories" presented a lot of breakdowns in communication, and problems in establishing the roles and making clear boundaries between them.

To sum up, using dyadic interviews allowed us to analyze the difficulties, consequences, and conflicts that result from taking on and abandoning many social roles, and to capture the processes of the micro- and nano-transitions in the social roles. Finally, thanks to the use of dyadic interviews, we were able to fully understand that telework is not an individual task, and that partners are important co-workers (voluntarily or involuntarily) involved in the work process and working practices.

\section{"MY STORY" - THE ROLE OF REFLEXIVITY IN CONSTRUCTING THE STUDY}

The study gave us an opportunity to develop our own reflexivity as researchers. As Hertz observes, apart from the four stories mentioned earlier, one needs to take into account two other stories: "our story", which is common to the researcher 
and the informant, and "my story", i.e. the story of the researcher, the resulting revelation of the researchers themselves [Hertz 1995: 447-448].

The figure of "my story" brings us to the researchers' subjectivity, treated as a potential for the development of the study. As Gabb and Fink showed, the researcher's subjectivity is a valuable aspect of the research process "which is salient in studies of personal lives, where connections and mirrored reflections, ambivalence and antipathy are inevitable" [Gabb, Fink 2018: 13]. They continue to say that both of them as researchers remained attentive to the findings that were brought up in their fieldwork and analysis; they were conscious about how their researcher subjectivities influenced the account to be produced and analyzed [Gabb, Fink 2018: 13]. Therefore, as Gabb and Fink underline, the three of us "remained open to the possibility of different interpretations of the same material since readings are not all in the text but are produced out of 'a complex interaction between reader and text"" [Gabb, Fink 2018: 13].

These joint interpretative practices were partly determined by simply working at a distance in the digital environment. In the course of our project, we used communication and management software (such as Trello, Asana, Google docs, Skype, Zoom.us), as well as tools that make collaboration and co-authorship an important element of practice (such as Google docs or Maxqda). This helped us to cooperate at a distance, to work simultaneously, to share our thoughts, intuitions, and sources, and to have them in one place.

In his study of 1980s lifestyles, in a work well-known among Polish sociologists, Andrzej Siciński introduced the concept of the "collective researcher". As proposed, a collective researcher emerges when a research team interprets data by discussing and negotiating the researchers' points of view [Siciński 1988: 16]. In his perspective, the collective approach is a matter of choice.

In our case - following the use of the different technologies and tools mentioned above - it became, to some extent, the only possible way. Discussion and negotiation of opinions and points of view are sparked automatically when we work together online. An individual researcher is, then, forced to cooperate, owing to the very nature of the new communication technologies. Hence, working at a distance, in the digital environment, not only facilities communication or speeds up the very process of work but it also impacts the way we deal with data and how we analyze them. This process becomes distributed, though not blurred, since we were following assumed procedures. However, it is obvious for us that we were working as collective researchers rather than a group of individual researchers. This has further implications for the question of authorship, since one may raise the question who is the author of a particular part of a text. Here, we are only 
highlight this problem. In times of the interrelated ideas of digital humanities and the quantification of scholars' work, it will - to our minds - become one of the cruxes of contemporary scientific work. However, this style of work, determined by new communication technologies, not only "helps" but also "transforms" the very idea of scientific work and authorship. If written by more than one author, a Google docs document becomes a palimpsest, a multi-layered text where comments, corrections and ideas merge to such an extent that makes it impossible to easily recognize authorship and assess someone's input. A text is, then, not simply composed of a number of sections written by different authors. In fact, the whole practice of interpreting and writing becomes collective. This happens when we agree that everyone may comment on the parts written by others and add, remove or develop some fragments. In this way, scientific work becomes a collective practice, which was the case with our team. We would like to stress that in our project, and in our view, collective research practices and blurred authorship are not a drawback but a challenge and a fact that raises scientific self-awareness and develops research methods.

Elizabeth Chaplin, commenting on autoethnography, stress that one of its features is bringing "the personal into the social science" [Chaplin 2011]. In autoethnography, it is the researcher and his/her narrative that become "the principal subject of the research project" [Chaplin 2011:243]; s/he is brought to the foreground from the "shadowy position" [Chaplin 2011: 243] designed for him/ her in the positivist approach:

Underlying this distinctive methodological approach is the conviction that a narrative that closely documents the researcher's personal thoughts, feelings, and actions and relates them to the wider social world will give the reader a richer and more intimate experience of that world than they would get from the generalized results of a conventional social scientific research project [...] An autoethnographic project [...] often hopes to bring aspects of the research process into the open that, in a more conventional project, would remain hidden: for example, personal opinion, informal asides, doubts and worries, or confessions [Chaplin 2011: 243].

The fact that project itself was carried out on the basis of teleworking constituted part of the analyzed data of our study. Our trials of various tools for teamwork planning at a distance and the framing and negotiation of borders not only increased our reflexivity with respect to the subject matter but it also led us to refine and develop our research tools (change of interview scenarios, completion and reconfiguration of methods). 
However, it must be stressed that while we wish to make the presence of the researchers in the text clearly visible, we wanted to avoid falling into excessive "egocentrism". To clarify - we treated analytical autoethnography as an effective tool to achieve the most important goal of our project: to gain the deepest possible understanding of what telework means for the partners and the spatiotemporal realities of their homes. Therefore, one can read this text, along with the other articles and the book that are the outcomes of our project, as a piece of analytical autoethnography [Anderson 2006]. Such an approach to autoethnography (despite more or less severe criticism - see Denzin 2006) is important not only because it describes one's own experiences, but also because it makes it possible to confront the observations of others.

This approach helped us to avoid a serious danger, i.e., identifying the act of experiencing a culture with our knowledge of it. At the same time, it enables readers to observe changes in views and relationships while working in the field. In this way, one can see a "shift of theory and methods of action" [Holman 2009: 17]. By such a mode of describing the study, we were able to present reality in the process of change, experience and creation. This perspective seemed more appropriate to describe such a complex and ever-changing field as the home, especially one in which two contradictory realities of work and private life meet because of the telework.

\section{OUR STORY - ON BUILDING RELATIONS}

Creating "our story", i.e., the story that is common to the researcher and the informant, is crucial to gain access and to collect valuable data. Building relations and writing "our story" in the case of the presented research was a crucial, but relatively simple task.

First of all, working in academia involves a constant search for a working space, and one often works from home on a very similar basis as teleworkers [Mills, Rath 2012; Gornall, Salisbury 2012]. Indeed, much of our work must be completed as "homework", outside of academia and after classes, on the basis of telework [see: "holiday fiction" Kowzan 2016]. As co-researchers involved in the study, we share a similar experience of academia penetrating private life.

Secondly, thanks to our previous studies, we have experience of researching the private life of couples and the private spaces of living (household duties, Żadkowska; residence, Jewdokimow; and the house as a social construct, Gądecki), as well as our family experiences (the birth and raising of children, seeking additional sources of financing the home budget, health issues). In our 
study, the three of us were also conscious of our gender, relationships and parental status (the number and age of our children), financial status, and additional professional challenges we are involved in, and were mindful of the "situation, feelings and context" [Gabb, Fink 2018: 13] that we vividly discussed during our online meetings. Therefore, as Gabb and Fink underline, the three of us also "[remained] open to the possibility of different interpretations of the same material since readings are not all in the text, but are produced out of 'a complex interaction between reader and text"' [Gabb, Fink 2018: 13].

It is easier to build a trust relationship during a combined interview, which is so important in the interview [Gudkowa 2012: 124]. We built trust, starting with the individual interviews. Our conclusions show that when researching couples, one should take care of the symmetry. A disadvantageous situation is when there is an imbalance between the researcher and the respondents. This might be caused, for example, by the fact that an interview with a dyad takes place between individual interviews, or when one of the couple does not participate in the combined interview. This creates a feeling of exclusion, alienation, and danger, and it is difficult to build trust in such a situation. Using this method, it is also possible to reach different aspects of the couple's knowledge (each partner talks differently about the same thing) and it helps to fill gaps in the memory of one of the partners [Arksey 1996 for Seymour, Dix, Eardley 1995].

On the other hand, dyadic interviews carry the risk of one of the respondents dominating, and they might provoke confusion and disagreement among the respondents [Arksey 1996]. The situation of the interview itself may give rise to tensions due to new, controversial, suppressed or uncomfortable topics for one or both partners. Arksey writes that the interview is criticized for the risk of unreliability; the couples try to present themselves in a favorable light, constructing a better image, producing more data that they have agreed upon, and they can «use» the interview situation to validate or justify their actions, or to normalize the situation in the relationship [Arksey 1996]. This argument is completely different from the argument Polak and Green discussed [Polak, Green 2016]. Arksey claims that an interview with a couple is risky, both when "persuading» each partner to participate, and during the research when it is necessary to «keep» both partners in the research process [Arksey 1996, Pahl 1989]. Therefore, in the design of our study, we mixed individual interviews with joint ones ${ }^{3}$.

3 We wrote more about the triangulation of methods in a methodological article entitled "Methodological Aspects of the Qualitative Research on Couples: Notes from the Field" [Żadkowska et al. 2018] 


\section{THE STORY - ACCESS TO THE RESEARCH FIELD - THE TRULY OBJECTIVE CAMERA}

Studying the home environment creates problems related to the most intimate and most personal sphere of human life. As Arlene Vetere and Anthony Gale state [Vetere, Gale 1987], it is more difficult to get access to such a research field and to develop the research program for a longer period.

The first mentioned difficulty, i.e., access to the private sphere, was easy to solve. Telework, as work performed at home, makes access to the field considerably easier - during initial talks with potential respondents, we stressed that the first visit and interview should be held at their "place of work". By reframing the home as the "place of work", we had a chance to avoid the first problems of studying the home.

During the first visits, we took the roles of "friendly observers", which seemed to be the most appropriate for our tasks, and it opened up the context of the home and community of experiences. Thanks to creating a non-hierarchical relationship between the informant and the researcher, we were able to make additional tours around the informants' homes [Oakley 2013].

The second difficulty, i.e., being present for a long time in their home, was resolved by applying auto-photo ethnography and teleworker diaries. We were convinced that the researchers who were observing the practices in the home, could, even unintentionally, suggest the existence of specific practice patterns, which would provide a benchmark for the actual practices that take place in the home context. That is why we decided to apply photo essays - provided by the informants - documenting the spatial and temporal aspects of working at home. The auto-photo-ethnography was based on the use of disposable cameras ( 27 shots max.) used over one week ( 3 photos per day), and one-week, on-line diaries on a platform provided by the researchers. Both methods allowed us to maintain a balance between acceptable standards of science and the natural interactions with family members in the analysis of the home reality [Jordan 2006].

Our research field (i.e., offices created in the private space of houses and apartments) makes it possible to treat our study broadly as a case of organizational ethnography. Teleworking units situated in homes are organizational units of the new economic trends. Explaining how organizations are socially and materially constructed through the activities and efforts of particular actors, it is important to focus on their work and specific activities that constitute the organization's routine. Stephen Barley and Gideon Kunda observe that, today, both popular and academic attempts to capture a post-bureaucratic organization are partly hampered 
by inadequate concepts of work. Organization theorists need to focus more on work itself, and its reintegration into organizational research can benefit the field [Barley, Kunda 2001]. This, in turn, requires the study of work practices and their relationship in situ, or - as we may argue - an ethnographic study.

Thanks to "the story" perspective, our study is also a critical examination - it shows the differences between the work-at-home phenomenon and telecommuting practices on the one hand, and their representations on the other. Carol Wolkowitz claims that work at home is "invisible" [Wolkowitz 2006: 166] since it is performed outside the public sphere and, hence, the public gaze. It is represented by social images that, as we said, have very little to do with the reality of work-at-home practices (and, as social representations, they are recognized as a normative point of reference, partially influencing these social practices). Since our study makes telecommuters' work visible, it also becomes a part of a social discourse on these practices and has a potentially transformative power by introducing (making public) alternative representations of work-at-home phenomena (representations emerging from our study). This movement of "unveiling" these practices also means transferring them from "private" to "public", and, by doing so, makes public discussion concerning these issues possible. In this way, our analysis may be understood as critical.

\section{DISCUSSION AND CONCLUSIONS}

The "return" of work to the home space causes a wide spectrum of unintended consequences, which manifest themselves also at the symbolic level of "togetherness". Telework, as a form of paid work, blurs the boundaries in at least three important dimensions: temporal, spatial and social. There are no longer "proper" time divisions ("before" or "after work"), there are no spaces "free from work" in our homes (bedrooms, kitchens, and children's rooms become working places), we have a problem with fulfilling our roles as mothers, fathers, wives, husbands, neighbors, partners, sons, and daughters, etc. because they are mixed with our worker/professional roles. "Couples come together in the home emotionally and physically and build their sense of togetherness through relationship practices that are embedded not only in the fabric of its rooms and furniture but also in the ways 'home life' is imagined" [Gabb, Fink 2018:143]. In "Enduring Love? Couple Relationships in the 21st Century" [Gabb, Fink 2018], although without referring specifically to teleworkers, Gabb and Fink describe the management of boundaries between work and home as difficult. This is especially the case when working online becomes an ever-present and persistent feature of a couple's life 
together. As a result, the partner who does not work at home might feel lonely and neglected, forced to spend time together apart at home [Gabb, Fink 2018: 58-59].

The main concern of our study, at least at the outset, was the material reality of the home, what is private and public, and how the emergence of paid work in the form of telework modifies the spatial and social realities of the home. Thus, it can be said that the starting point for the research was the home understood as a private space. Studying the private space and paid work, we tried to adopt a performative approach. Our understanding of performativity is close to that proposed by Victor Turner, who emphasizes the importance of performative activities in negotiating different situations and states in more or less established activities of everyday life. Such an understanding of performativity emphasizes the importance of repetitive actions as an element of social reality without the need to refer to the creator or the maker [Pink 2004]. For the purposes of this text, the aspect of creating and co-creating reality lies in the practice of paid domestic work. It is also worthwhile to apply a performative approach to reflection on the very essence of the home. The phenomenon and place of the home extend in time between the past (memories and nostalgia), the daily life that takes place in the present, and the future (dreams and fears related to what is about to happen).

In terms of the results of our empirical investigation, the following should be highlighted. The study revealed a gap between the official narratives on telecommuting, shared by the media, and the actual practices related to this social phenomenon. Work-at-home is frequently presented as easy, simple, accessible, and almost effortless. These characteristics are driven by the fact that one works at home, hence, in a familiar and cozy place. However, a closer look at how this is conducted uncovered that the location of work provokes a variety of challenges rather than facilitating the action. Telecommuters have to struggle with the cultural understanding of the home and its contradictory nature in comparison to work. Simply speaking, working at home pushes individuals to reconfigure their lifestyle. It is challenging because it is not only cultural associations but also the material layer of the home space (the non-humans) that contribute to its home-ness. Hence, individuals have to re-orchestrate their living space and their habits. Our study shows that the situation is difficult for the other inhabitants as well. Thanks to the interviews in pairs that we conducted, we noticed that work-at-home is a phenomenon that affects not only the individuals who actually telecommute but also the other people in the relationship. Hence, we claim that, contrary to the dominant, official narratives, individuals who telecommute should be understood not as flexible but rather as limp or soft. The same is true about working conditions - working at home does not introduce elastic conditions but 
rather weak ones, which are soft or fluid. In the second modernity era, it is the individual or the "family" who has to give shape to this fluid situation.

According to researchers who study work and organization, it is difficult to discuss work without an intimate knowledge of the practices involved. That is why studies of industrial work entailed some form of field research and often made use of qualitative data. In recent years, qualitative research has enjoyed something of a resurgence. However, contemporary qualitative researchers tend to rely more heavily on interviews and content analysis than, for example, observation and other techniques. Although useful for studying points of view and meaning, such techniques are less appropriate for studying work as a practice: work is contextualized, and that is why people often cannot articulate how they do what they do unless they are in the process of doing it [Schon 1983, Suchman 1987]. Consequently, as Barley and Kunda wrote, "whether qualitatively or quantitatively oriented, most contemporary students of organizing employ methods that distance them from the kind of data needed for making grounded inferences about the changing nature of work and work practices" [Barley, Kunda 2001: 81]. Our paper is a kind of methodological reflection that wants to link, on the one hand, the daily lives of teleworkers and their partners (treated as a "teleworking unit") and, on the other hand, theoretical frameworks, such as toolkits or orchestration. This approach allowed us to grasp how telework is organized as a social phenomenon and in a strictly local context, i.e., home, and unveiling mechanisms which make work a key factor for one's identity, time and spatial arrangements.

The ethnographic approach that we implemented at the beginning was further developed during our study in order to more comprehensively cover the phenomenon. We started from an "individualistic point", i.e., collecting data on individuals, and ended up a "collective point", i.e., understanding work at home as a phenomenon that one has to study in reference to other local actors - partners and things that are involved in constructing a workplace and work practices.

This "collectiveness" also affected our own research practices. At some point, we agreed that we are "collective researchers" rather than a group of three individuals. This articulation was rooted in our understanding of how our own distance working and new communication technologies impact our research practices. The cooperation using online tools while analyzing outcomes and writing articles and the book turned out to be very fruitful, although we missed the opportunity for more face-to-face meetings. The topic of research practices conducted remotely seems to be a vital idea for a new study. 


\section{REFERENCES}

Alasuutari Perti. 1995. Researching culture: Qualitative method and cultural studies. London: Sage.

Anderson Leon. 2006. "Analytic autoethnography". Journal of Contemporary Ethnography 35(4): 373-395.

Ariès Phillippe, Georges Duby, Arthur Goldhammer (eds.). 1988. A history of private life: Revelations of the medieval world. Belknap Press.

Arksey Hillary. 1996. Collecting data through joint interviews. Social Research Update.

Barley Stephen R., Gideon Kunda. 2001. "Bringing work back in”. Organization Science 12(1): 76-95.

Bourdieu Pierre. 1984. Distinction: A social critique of the judgement of taste. Harvard University Press.

Certeau Michel de. 1984. The practice of everyday life. Berkeley: University of California Press,

Certeau Michel de, Pierre Mayol. 1998. The practice of everyday life: living and cooking. Volume 2. University of Minnesota Press.

Chaplin Elisabeth. 2011. The photo diary as an autoethnographic method. In: The SAGE handbook of visual research methods, E. Mangolis, L. Pauwels (eds.), 241-262. Los Angeles, London, New Delhi, Singapore, Washington DC.

Denzin Norman K. 2006. "Analytic autoethnography, or deja vu all over again". Journal of Contemporary Ethnography 35(4): 419-428.

Ellison Nicole. 1999. "Social impacts: New perspectives on telework". Social Science Computer Review 17(3), 338-356.

Estrada Lopez Silvia. 2002. "Work, gender, and space: Women's home-based work in Tijuana, Mexico". Contributions to Asian Studies 18(2-3): 169-195.

Gabb Jaqui. 2009. "Researching family relationships: A qualitative mixed methods approach". Methodological Innovations Online 4(2): 37-52.

Gabb Jaqui, Janet Fink. 2018. Enduring love? Couple relationships in the 21st century. Palgrave MacMillan.

Gądecki Jacek, Marcin Jewdokimow, Magdalena Żadkowska. 2017. Tu się pracuje! Socjologiczne studium pracy zawodowej prowadzonej $w$ domu na zasadach telepracy. Kraków: Wydawnictwo Libron.

Gornall Lynne, Jane Salisbury. 2012. "Compulsive working, 'hyperprofessionality' and the unseen pleasures of academic work". Higher Education Quarterly 66(2): 135-154.

Grucza Bartosz et al. 2012. Elementarz telepracy. Warszawa: PZPPIiT Lewiatan.

Guba E.G., Lincoln Y.S. 1994. Competing paradigms in qualitative research. In: Handbook of Qualitative Research, N.K. Denzin, Y.S. Lincoln (eds.), 105-117. Thousand Oaks, CA Publications.

Hand Martine, Elisabeth Shove. 2004. "Orchestrating concepts: Kitchen dynamics and regime change in good housekeeping and ideal home, 1922-2002". Home Cultures 3(1): 235-256.

Hertz Rosanna. 1995. "Separate but simultaneous interviewing of husbands and wives: Making sense of their stories Wellesley College". Qualitative Inquiry 4(1): 429-451.

Holman Jones S. 2009. Autoetnografia. Polityka tego, co osobiste. W: Metody badań jakościowych, N.K. Denzin, Y.S. Lincoln (eds.), 175-211. Warszawa: Wydawnictwo Naukowe PWN.

Horolets Anna. 2016. "Badacz jako gość”. Przegląd Socjologii Jakościowej 12 (3): 54-69. 
Jepperson Ronald L., Ann Swidler. 1994. "What properties of culture should we measure?". Poetics 22(4): 359-371.

Jordan Amy B. 2006. „Make yourself at home: The social construction of research roles in family studies." Qualitative Research 6(2): 169-185.

Kacperczyk Anna. 2014. "Autoetnografia - technika, metoda, nowy paradygmat? O metodologicznym statusie autoetnografii”. Przeglad Socjologii Jakościowej 10(3): 32-75.

Kaufmann Jean-Claude. 1995. Trame coniugali. Panni sporchi e rapporto di coppia. Bari: Dedalo.

Kowzan Piotr, Małgorzata Zielińska, Agnieszka Kleina-Gwizdała, Magdalena Prusinowska. 2016. Nie zostaje mi czasu na pracę naukowa. Warunki pracy osób ze stopniem doktora, zatrudnionych na polskich uczelniach Gdańsk-Bydgoszcz-Warszawa: Nowe Otwarcie Uniwersytetu, https://wns.ug.edu.pl/sites/default/files/_nodes/strona-wns/55234/files/nie-zostaje-mi-czasu-na-pracc499-naukowc485-raport-nou3.pdf [dostęp: 20.09.2018].

Ladner Sam. 2009. "Agency time: A case study of the postindustrial timescape and its impact on the domestic sphere". Time \& Society 18(2): 284-305.

Lee Heejin, Jonathan Liebenau. 2002. A new time discipline: Managing virtual work environments. In: Making time: Time and management in modern organizations, R. Whipp, B. Adam, I. Sabelis (eds.), 126-139. New York: Oxford University Press.

Mccarthy Jane R., Val Gillies, Janet Holland. 2003. "Multiple perspectives on the "family' lives of young people: Methodological and theoretical issues in case study research". International Journal of Social Research Methodology 6(1): 1-23.

McDowell Linda. 2007. "Spaces of the home: absence, presence, new connections and new anxieties". Home Cultures 4(2): 129-146.

Mills David, Jean Rath. 2012. "Academia as workplace”. Higher Education Quarterly 66(2): 129-134.

Mirchandani Kiran. 1999. "Legitimizing work: Telework and the gendered reification of the work-nonwork dichotomy". Canadian Review of Sociology 36(1): 87-107.

Nansen Bjorn, Michael Arnold, Martin R Gibbs, Hilary Davis. 2009. "Domestic orchestration: Rhythms in the mediated home". Time \& Society 18(2-3): 181-207.

Nicolini David. 2009. Zooming in and zooming out: A package of method and theory to study work practices, In: Organizational ethnography: Studying the complexities of everyday life, S. Ybema, D. Yanow, H. Wels, F. Kamsteeg (eds.), 120-138. London: Sage.

Nippert-Eng Christena. 1996. Home and work: Negotiating boundaries through everyday life. Chicago: University of Chicago Press.

Oakley Ann. 2013. Interviewing women: A contradiction in terms? In: Doing feminist research, Roberts H. (ed.), 30-61. London: Routledge.

Pahl Jan. 1989. Money and marriage. Basingstoke: Macmillan.

Pink Sarah. 2004. Home truths. Gender, domestic objects and everyday life. Oxford, New York: Berg.

Polak Louisa, Judith Green. 2016. "Using joint interviews to add analytic value". Qualitative health research. 26(12): 1638-1648.

Rybczynski Witold. 1987. Home: A short history of an idea. New York: Penguin.

Schon Donald. 1983. The reflective practitioner: How professionals think in action. New York: Basic.

Seymour Julie, Dix Gill, Tony Eardley. 1995. Joint accounts: Methodology and practice in research interviews with couples. York: Social Policy Research Unit. 
Siciński Andrzej. 1988. Style życia w miastach polskich (u progu kryzysu). Wrocław: Zakład Narodowy im. Ossolińskich.

Sowińska-Milewska Daria. 1999. Telepraca w praktyce. Warszawa: Fundacja Centrum Promocji Kobiet.

Spytek-Bandurska Grażyna. 2015. Telepraca jako nietypowa forma zatrudnienia w Polsce: aspekty prawne i spoleczne. Warszawa: Oficyna Wydawnicza ASPRA-JR.

Suchman Lucy A. 1987. Plans and situated Action: The problem of human-machine communication. Cambridge University Press, Cambridge.

Swidler Ann. 2001. Talk of love: How culture matters. Chicago: University of Chicago Press.

Urry John. 2004. "Connections". Environment and Planning D: Society and Space 22(1): 27-37.

Watkins Susan, Ann Swidler. 2009. "Hearsay ethnography: Conversational journals as a method for studying culture in action". Poetics 37(2): 162-184.

Warren Carrol. 2010. "Pride, shame and stigma in private spaces", Ethnography 11(3): 425-442.

Wolkowitz Carol. 2006. Bodies at work. London: Sage.

Zalega Tomasz. 2009. "Praca zdalna - obraz przemian w Polsce i wybranych krajach UE". Master of Business Administration 4(39): 35-45.

Żadkowska Magdalena, Marta Olcoń-Kubicka, Jacek Gądecki, Joanna Mizielińska, Agata Stasińska, Filip Schmidt, Mateusz Halawa. 2018. "Methodological aspects of the qualitative research on couples: Notes from the field". Studia Socjologiczne 230(3): 49-61.

Jacek Gadecki

Marcin Jewdokimow

Magdalena Żadkowska

\section{JEDNO STUDIUM - RÓŻNE HISTORIE. PERSPEKTYWA LĄCZENIA WIELU METOD W BADANIU TELEPRACY}

Streszczenie

Głównym celem artykułu jest refleksja metodologiczna nad badaniem telepracy realizowanym w przestrzeni prywatnej. Rekonstruujemy proces tworzenia „opowieści“ o telepracy, która zaczyna się od ,punktu indywidualnego” (jego/jej opowieść) o telepracowniku/nicy traktowanych jako jednostka i kończy w „punkcie zbiorowym”, definiującym telepracę jako zjawisko, które należy badać w odniesieniu do innych aktorów lokalnych (ich opowieść) i na które wpływa perspektywa autoetnograficzna grupy badaczy (nasza opowieść).

Słowa kluczowe: telepraca, podmiot pracujący, etnografia, triangulacja metod, wywiad z diadą 